medRxiv preprint doi: https://doi.org/10.1101/2021.07.23.21261034; this version posted July 26,2021 . The copyright holder for this preprint (which was not certified by peer review) is the author/funder, who has granted medRxiv a license to display the preprint in perpetuity.

All rights reserved. No reuse allowed without permission.

\title{
Running related biomechanical risk factors for overuse injuries in distance runners: A systematic review considering injury specificity and the potentials for future research
}

\author{
Steffen Willwacher ${ }^{1,3}$, Markus Kurz ${ }^{2}$, Johanna Robbin ${ }^{1,3}$, Matthias Thelen ${ }^{3}$,Joseph Hamill ${ }^{4}$, \\ Luke Kelly ${ }^{5}$, Patrick Mai ${ }^{3}$ \\ ${ }^{1}$ Department for Mechanical and Process Engineering, Offenburg University of Applied \\ Sciences, Offenburg, Germany \\ ${ }^{2}$ Department of Quality Technology \& Mechanical Engineering, Mid Sweden University, \\ Östersund, Sweden \\ ${ }^{3}$ Institute for Biomechanics and Orthopaedics, German Sport University Cologne, Cologne, \\ Germany \\ ${ }^{4}$ Biomechanics Laboratory, University of Massachusetts, Amherst, MA, USA \\ ${ }^{5}$ School of Human Movement and Nutrition Sciences, University of Queensland, St. Lucia, \\ Queensland, Australia
}

\begin{abstract}
Objective

To identify and evaluate the evidence of the most relevant running-related risk factors (RRRFs) for running-related overuse injuries (ROls) and to suggest future research directions.
\end{abstract}

Design

Systematic review considering prospective and retrospective studies. (PROSPERO_ID: 236832)

\section{Data sources}

Pubmed. Connected Papers. The search was performed in February 2021.

\section{Eligibility criteria}

English language. Studies on participants whose primary sport is running addressing the risk for the seven most common ROls and at least one kinematic, kinetic (including pressure measurements), or electromyographic RRRF. An RRRF needed to be identified in at least one prospective or two retrospective studies.

\section{Results}

Sixty-two articles fulfilled our eligibility criteria. Levels of evidence for specific ROls ranged from conflicting to moderate evidence. Running populations and methods applied varied considerably between studies. While some RRRFs appeared for several ROIs, most RRRFs were specific for a particular ROI. The biomechanical measurements performed in many studies would have allowed for consideration of many more RRRFs than have been reported, highlighting a potential for more effective data usage in the future.

\section{Conclusion}

This study offers a comprehensive overview of RRRFs for the most common ROls, which might serve as a starting point to develop ROI-specific risk profiles of individual runners. Future work should use macroscopic (big data) approaches involving long-term data collections in the real world and microscopic approaches involving precise stress calculations using recent developments in biomechanical modelling. However, consensus on data collection standards (including the quantification of workload and stress tolerance variables and the reporting of injuries) is warranted. 
medRxiv preprint doi: https://doi.org/10.1101/2021.07.23.21261034; this version posted July 26,2021 . The copyright holder for this preprint (which was not certified by peer review) is the author/funder, who has granted medRxiv a license to display the preprint in perpetuity.

All rights reserved. No reuse allowed without permission.

\section{Introduction}

Overuse injuries in runners (ROIs) are widespread, with a reported overall incidence of 19.4 to $79.3 \%$ [1]. Depending on the type of runner, definitions of injury, and follow-up periods, running-related injury incidence rates range between 2.5 to 33.0 injuries per 1000 hours of running [2]. The origins of ROls are complex [3,4] but principally result from an accumulation of repetitive stress applied on the body without sufficient rest for tissue remodelling resulting in a degenerative response [5]. The stress response is a function of both tissue characteristics (influenced by lifestyle and genetic factors) and stress application characteristics (e.g., amplitude, frequency, duration) [6]. However, the non-invasive determination of these stresses is challenging as is the measurement of stress accumulation in everyday life and sports [7]. To determine structure specific stresses, computational models need to integrate precise anatomical information (e.g., biological tissues' properties and geometry) and the potential neuromuscular control strategy that governs force and power production [8].

Therefore, researchers and practitioners often try to predict injury risk based on less direct and less computational and information-expensive biomechanical parameters as surrogate variables to link running biomechanics and injury risk. Such biomechanical running-related risk factors (RRRFs) include kinematic and kinetic parameters derived from ground reaction force, pressure mapping, electromyographic, and motion capture data. Using this approach, runners at risk of an $\mathrm{ROI}$ can be identified, however, to prevent ROls, further knowledge on causeeffect relationships is needed [9].

Within a framework of injury development $[10,11]$, the most relevant RRRFs could serve as a source for the improvement of technical (e.g., running shoes or foot orthoses / insoles), training and/or feedback system interventions (e.g., in gait retraining or through "digital coaches" based on wearable sensor information) by targeting populations at risk. Research on RRRFs employs different research designs and populations. The wealth of information is challenging to oversee.

Therefore, the aim of this review article is: (1) to identify the most relevant RRRFs and evaluate their evidence concerning the most prevalent ROIs; and (2) to suggest future directions of research to improve the understanding of the relationship between running biomechanics and overuse injury development while considering the interplay between RRRFs, workload characteristics and individual, structure-specific stress tolerances.

\section{Methods}

\section{Search strategy and risk factor extraction}

The systematic review aimed to extract the evidence for RRRFs for the ROls with the highest prevalence and incidence. Therefore, based on the work of Lopes et al. [12], we examined RRRFs for the following ROls: Medial tibial stress syndrome (MTSS), Achilles tendinopathy (AT), plantar fasciitis (PF), patellar tendinopathy (PT), iliotibial band syndrome (ITBS), tibial stress fracture (TSF), hamstring tendinopathy (HT), and patello-femoral pain syndrome (PFPS). We followed the reporting items for Systematic Reviews and Meta-analyses (PRISMA) guidelines [13]. Before starting the literature review, we registered this study at PROSPERO (record ID 236832).

We scanned the Pubmed database for articles comparing the running biomechanics of injured and uninjured individuals for the seven most common ROls. For each ROI, we used an injury- 
medRxiv preprint doi: https://doi.org/10.1101/2021.07.23.21261034; this version posted July 26,2021 . The copyright holder for this preprint (which was not certified by peer review) is the author/funder, who has granted medRxiv a license to display the preprint in perpetuity.

All rights reserved. No reuse allowed without permission.

specific search string (for details, please refer to the Supplementary Digital Content (SDC)). In short, each search string comprised combinations of runn* (i.e., the main activity), the injury location (e.g., femur*), multiple keywords to characterise injury-specific physical complaints (e.g., risk OR tend ${ }^{*}$ OR pain), and the study design (e.g., prospective OR retrospective). We used an additional combination of keywords to obtain original English articles involving human participants (SDC). The initial search for ITBS, MTSS, and HT took place on February 4, 2021. One day after (February 5, 2021), the search strings for AT, PT, PFPS, PF, TSF were applied. Search results, including titles and abstracts, were uploaded to the web interface of rayyan.qcri.org [14]. We then screened titles and abstracts of the articles using the following criteria:

Inclusion criteria:

- Studies in the English language

- Prospective or retrospective studies addressing at least one of the ROls of interest and relating injury risk to at least one RRRF

- Studies considering kinematic, kinetic (including pressure measurements), or electromyographic RRRFs

- The primary sport of the investigated study sample was running

Exclusion criteria:

- No RRRF analysed

- Studies that sampled from populations where distance running was not the primary sport

- Studies addressing biomechanical risk factors during dynamic activities other than running (e.g., walking or stair climbing)

- Studies addressing anthropometric factors (e.g., leg alignment, foot posture index) or strength measurements (e.g., toe strength or hip abduction strength)

- Studies including military or physical education students due to the unknown effects of concurrent training

- Studies (obviously) publishing results from the same subject sample as in a previous publication of the same group

- Non-original articles (e.g., reviews or conference articles) or articles not written in English

Two review team members independently selected titles and abstracts of studies found through the search strategy for potentially relevant studies after applying the inclusion and exclusion criteria. The selection of appropriate studies was discussed between the team members, and in the case of disagreements, they were resolved through consultation with another member of the review team. Subsequently, full texts were screened based on the same exclusion and inclusion criteria.

Additional sources were identified through the reference list of the eligible articles from the initial search and a co-citation method using the bibliographic coupling concept (http://www.connectedpapers.com).

Data on study characteristics were extracted from all included articles by members of the review team. Discrepancies were identified and resolved through discussion (with another reviewer if necessary). This data extraction included publication details (author and year), general information on injury type, specific running population, sample size, data collection method, running speed and footwear used during testing, and biomechanical outcome 
medRxiv preprint doi: https://doi.org/10.1101/2021.07.23.21261034; this version posted July 26,2021 . The copyright holder for this preprint (which was not certified by peer review) is the author/funder, who has granted medRxiv a license to display the preprint in perpetuity.

All rights reserved. No reuse allowed without permission.

variables. Furthermore, we determined whether potential risk factors found in other studies could have been calculated based on the reported data collection methods. We also collected data on participant characteristics (e.g., age, gender, height).

Relevance criterion for considering running-related risk factors

We considered an RRRF relevant if at least one prospective study or two retrospective studies from independent data collections found a significantly different value of an RRRF for a specific ROI.

\section{Quality rating and risk of bias assessment}

We followed the same procedure as in a previously published review [15] using selected components from the 'Quality Index' developed by Downs and Black [16]. The modified 'Quality Index' scale consists of 15 items. All points of the modified 'Quality Index' were summed to provide a quality score for each study. Studies scoring 11 or greater were considered to be of high quality, studies with scores of six to ten were considered to be of moderate quality and studies with scores of five or less were considered to be of low quality [17]. Outcomes were discussed in a team meeting, and discrepancies were resolved by consulting another reviewer.

Due to poor reliability observed in items addressing external validity in the complete Downs and Black Quality Index [16], we performed a separate risk of bias assessment using a 10point checklist, previously described in a systematic review of RRIs [12]. Each item was rated with either 1 , referring to a low risk of bias, or 0 , referring to a high risk of bias. If certain items could not be categorised, we assigned them a value of 0 . Overall, we summed up the ten items' scores. When less than half of the maximum possible points (i.e., $<=5$ of 10 possible points) were reached, we considered the study to have a high risk of bias.

To determine the strength of evidence of an RRRF for a specific ROI, we followed the same approach as a previous review focussing on the role of RRRFs for running injuries in general [18]. These authors used the following categories described in detail by van Tulder et al. [19]:

- Strong evidence: Consistent findings among three or more studies, including a minimum of two high-quality studies

- Moderate evidence: Consistent findings among two or more studies, including at least one high-quality study

- Limited evidence: Findings from at least one high-quality study or two low- or moderatequality studies

- Very limited evidence Findings from one low- or moderate- quality study

- Inconsistent evidence: Inconsistent findings among multiple studies (e.g., one or multiple studies reported a significant result, while one or multiple studies reported no significant result)

- Conflicting evidence We defined conflicting as contradictory results between studies (e.g., one or multiple studies reported a significant result in one direction, while one or multiple studies reported a significant result in the other direction)

- No evidence Results were insignificant and derived from multiple studies regardless of quality.

\section{Results}

After identification, screening, and applying the exclusion and inclusion criteria, 62 articles were included in the review (Fig. 1). 
medRxiv preprint doi: https://doi.org/10.1101/2021.07.23.21261034; this version posted July 26,2021 . The copyright holder for this preprint (which was not certified by peer review) is the author/funder, who has granted medRxiv a license to display the preprint in perpetuity.

All rights reserved. No reuse allowed without permission.

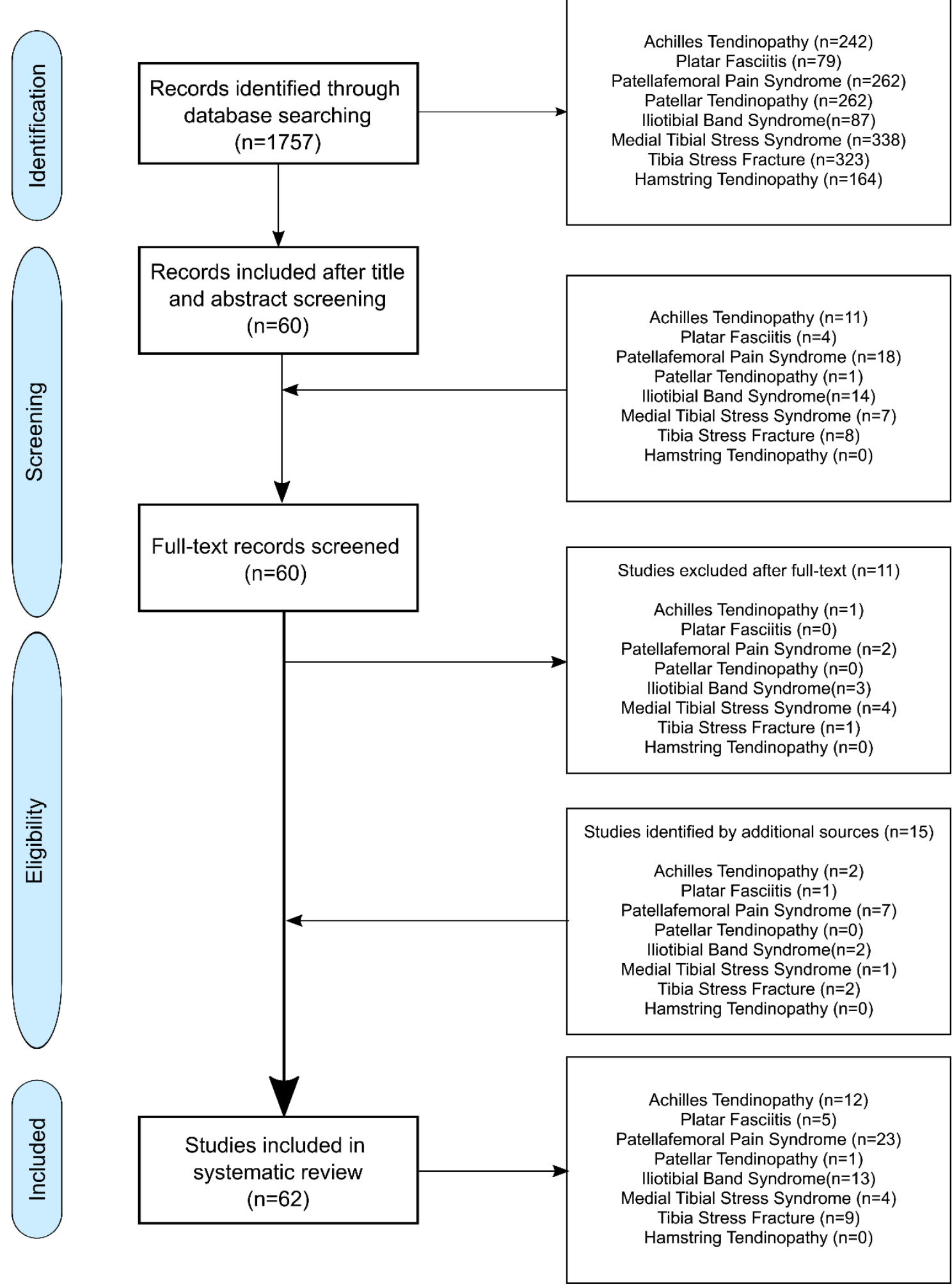

Figure 1: A FLOW-chart of the identification process. The numbers for articles per injury do not sum up to the total number of articles because some studies have addressed multiple running-related injuries.

In the following, we report the findings independently for each ROI considered. The findings are summarised graphically in Figure 2. Detailed results on study details, quality assessment and risk of bias rating can be found in the Supplementary Digital Contents (SDCs). 
medRxiv preprint doi: https://doi.org/10.1101/2021.07.23.21261034; this version posted July 26,2021 . The copyright holder for this preprint (which was not certified by peer review) is the author/funder, who has granted medRxiv a license to display the preprint in perpetuity.

All rights reserved. No reuse allowed without permission.

\section{Achilles tendinopathy (AT)}

We identified twelve studies (eleven retrospective, one prospective) that had analysed, in total, 115 different potential RRRFs for AT (SDC) through our systematic screening of the literature [20-31]. Out of these parameters, five RRRFs were identified in either two independent retrospective studies or one prospective study, following our predefined relevance criterion.

A high quality (B\&D: 13) prospective study with low risk of bias (ROBS: 8) using a pressure plate found that novice runners who developed AT within a ten-week follow-up period showed three differences in their plantar pressure application during the stance phase compared to novice runners who remained injury-free. A reduced antero-posterior displacement of the centre of pressure during the stance phase, higher vertical forces applied through the lateral part of the foot at the instant of forefoot flat, and a reduced time to peak force at the medial heel.

Further, two RRRFs related to the motion of the ankle joint in the frontal plane (rearfoot inversion-eversion relative to the tibia) were identified. Two medium quality retrospective studies (B\&D: 7-10), one with a high risk of bias (ROBS: 4), identified increased ankle range of motion from TD to maximum rearfoot eversion during the stance phase as RRRF $[22,30]$. Furthermore, more pronounced ankle inversion at initial contact with the ground was retrospectively identified as RRRF for AT by two medium quality studies with a high risk of bias (B\&D: 7-8; ROBSs: 4). Many additional parameters differed between runners suffering from AT compared to runners who did not. For a complete list of all parameters for all ROls, please refer to the SDC. However, these results were only found in single retrospective studies and did not follow our predefined quality criterion.

In summary, we identified limited evidence for a reduced anterior-posterior displacement of the centre of pressure, higher vertical forces applied through the lateral part of the foot at the instant of forefoot flat, and a reduced time to peak force at the medial heel during the stance phase as RRRFs for AT. We further found limited evidence for increased ankle inversion angle at initial contact and inconsistent evidence for ankle eversion range of motion from initial contact to peak rearfoot eversion during stance as RRRFs for AT (Fig. 3).

\section{Medial tibial stress syndrome (MTSS)}

Our search resulted in four (one prospective, three retrospective studies) studies addressing RRRFs for MTSS [20,32-34]. In these studies, 23 individual RRRFs were investigated (SDC). However, only three RRRFs matched our relevance criterion.

In a high quality (B\&D: 11; ROBS: 7 ) prospective study, competitive runners (NCAA Division 1) developing MTSS during a two-year follow-up period ran with greater peak rearfoot eversion relative to the tibia, and their ankle joints remained in an everted position for a longer time during the stance phase compared to runners not suffering from MTSS [32]. Furthermore, in the same study, runners developing MTSS had a higher contralateral peak pelvis drop during the stance phase compared to runners not suffering from MTSS [32]. The finding that runners with MTSS spend more time in eversion during stance was replicated in a moderate quality retrospective study (B\&D: 9; ROBS: 4) [20]. However, the finding that peak eversion is a risk factor for MTSS was not replicated in this study [20].

In summary, we found moderate evidence for eversion time during stance, inconsistent evidence for peak eversion, and limited evidence for peak contralateral pelvis drop during stance as RRRFs for MTSS (Fig. 3). 
medRxiv preprint doi: https://doi.org/10.1101/2021.07.23.21261034; this version posted July 26,2021 . The copyright holder for this preprint (which was not certified by peer review) is the author/funder, who has granted medRxiv a license to display the preprint in perpetuity.

All rights reserved. No reuse allowed without permission.

\section{Tibial stress fractures (TSF)}

We identified nine retrospective studies addressing RRRFs for TSF [31,35-42]. These studies considered 41 individual RRRFs (SDC). Three RRRFs followed our predefined relevance criterion. Two moderate quality studies (B\&D: 9-10; ROBS: 4-5) found higher peak ankle eversion during stance for runners with a history of TSF $[40,42]$. These same studies also reported greater peak hip adduction angles during stance for runners with a history of TSF compared to runners without a history of TFS [40,42]. Further, two moderate quality studies (B\&D: 9-10; ROBS: 4) found higher peak amplitudes of the free moment applied to the ground in runners with a history of TSF $[39,42]$.

In summary, we identified limited evidence for peak ankle eversion, peak hip adduction, and peak free moment amplitude as RRRF for TSF (Fig. 3).

\section{Plantar fasciitis (PF)}

Our search resulted in five retrospective studies considering 46 potential RRRFs for PF $[31,43-$ 46]. Two out of these parameters matched with our predefined relevance criterion. Runners with a PF history created higher instantaneous vertical loading rates of the ground reaction force in two retrospective studies [31,45]. One study was of high quality (B\&D: 11) but also a high risk of bias (ROBS: 3) [31], while the other study was of moderate quality (B\&D: 10) and also a high risk of bias (ROBS: 4) [45]. Further, two high-quality (B\&D: 11; ROBS: 3-5) studies found that runners with PF history applied vertical forces at a higher average loading rate to the ground $[31,43]$.

In summary, we found limited evidence for average and instantaneous vertical loading rates of the ground reaction force as RRRFs for PF (Fig. 3).

Iliotibial band syndrome (ITBS)

We found 13 studies (three prospective and ten retrospective) considering 71 potential RRRFs for ITBS [31,46-57]. Of these parameters, seven followed our relevance criterion. At the hip, conflicting evidence was found for the peak hip adduction angle. While one moderate quality retrospective study (B\&D: 10; ROBS: 4) [53] and one moderate quality prospective study (B\&D: 10; ROBS: 5\%) [56] found significantly higher peak hip adduction angles in runners with ITBS, three moderate (B\&D: 9-10; ROBS: 5) and two high quality (B\&D: 12; ROBS: 4-5) retrospective studies found reduced peak hip adduction angles during the stance phase in runners with ITBS compared to non-injured runners (Fig. 2).

A moderate quality (B\&D: 10; ROBS: 5) prospective study found higher peak external rotation during stance in runners who developed ITBS compared to their control group [56] (Fig. 2). At the knee, a moderate quality retrospective study (B\&D: 10; ROBS: 4) [53] and one moderate quality prospective study (B\&D: 10; ROBS: 5) [56] found significantly higher peak internal rotation angles during the stance phase in runners with ITBS compared to non-injured runners. Further, two high-quality retrospective studies (B\&D: 12-13; ROBS: 6) reported significantly higher peak knee adduction angles in runners with compared to runners without a history of ITBS [49,52]. When applying a computer model which calculates the kinematics of the ITB, Hamill et al. [55] identified increased ITB strain and strain rates in runners with compared to runners without a history of ITBS (Fig. 2). 
medRxiv preprint doi: https://doi.org/10.1101/2021.07.23.21261034; this version posted July 26,2021 . The copyright holder for this preprint (which was not certified by peer review) is the author/funder, who has granted medRxiv a license to display the preprint in perpetuity.

All rights reserved. No reuse allowed without permission.

In summary, our systematic review established moderate evidence for increased peak knee adduction angle, limited evidence for increased ITB strain, increased ITB strain rate and increased peak femur external rotation. Further, we found inconsistent evidence for increased peak knee internal rotation angle and conflicting evidence for peak hip adduction as an RRRF for ITBS (Fig. 3).

\section{Patello-femoral pain syndrome (PFPS)}

Twenty-three studies (four prospective and 19 retrospective) were included in the systematic review [31,58-61,61-78]. These studies analysed in total 114 potential RRRFs (SDC). Of these, eleven RRRFs matched our predefined relevance criterion. Longer contact time was identified as an RRRF for PFPS in two high-quality (B\&D: 11) retrospective studies with a low risk of bias (ROBS: 5-6)[71,74]. Several plantar pressure-related variables were identified by one high-quality (B\&D: 11) prospective study with a low risk of bias (ROBS: 7) [70]. These were an increased peak vertical force at the lateral heel (i.e., initial contact), as well as at the $2^{\text {nd }}$ and $3^{\text {rd }}$ metatarsal heads. Further, a reduced time to peak force at the medial and lateral heel were found. Two retrospective studies (B\&D: 10-11; ROBS: 5-6) related a reduced braking impulse of the horizontal ground reaction force with an increased risk for PFPS [71,74] (Fig. 2).

One high-quality (B\&D: 11) prospective study with low risk of bias (ROBS: 70\%) found greater internal knee abduction angular impulses in runners developing PFPS compared to noninjured controls [67] (Fig. 2). At the hip, higher peak adduction angles were identified as risk factors by one high quality prospective study with low risk of bias (D\&B: 11; ROBS: 8) [62] and two retrospective studies (D\&B: 10; ROBS: 5-6) [69,72]. Further, three moderate quality retrospective studies (B\&D: 10, ROBS: 4-6) suggested that an increased peak hip internal rotation angle was associated with PFPS $[60,69,72]$. A moderate quality prospective study with low risk of bias (B\&D: 8; ROBS: 7) found increased average internal hip abduction moments in runners who developed PFPS compared to runners who did not [63] (Fig. 2).

In summary, we found limited evidence for above mentioned plantar pressure-related parameters, increased internal knee abduction angular impulse, and increased average hip internal abduction moments during stance. Further, moderate evidence for reduced braking impulse of the ground reaction force and longer ground contact times, and inconsistent evidence for increased peak hip adduction and internal rotation angles during stance were found (Fig. 3).

Patellar and hamstring tendinopathy (PHT)

A moderate quality study with a high risk of bias (B\&D: 7; ROBS: 3) analysed 42 potential RRRFs for PHT [79]. However, since this was the only study, our predefined relevance criterion was not met. We could not identify a study focussing on RRRFs for hamstring tendinopathy. 
medRxiv preprint doi: https://doi.org/10.1101/2021.07.23.21261034; this version posted July 26,2021 . The copyright holder for this preprint (which was not certified by peer review) is the author/funder, who has granted medRxiv a license to display the preprint in perpetuity.

All rights reserved. No reuse allowed without permission.

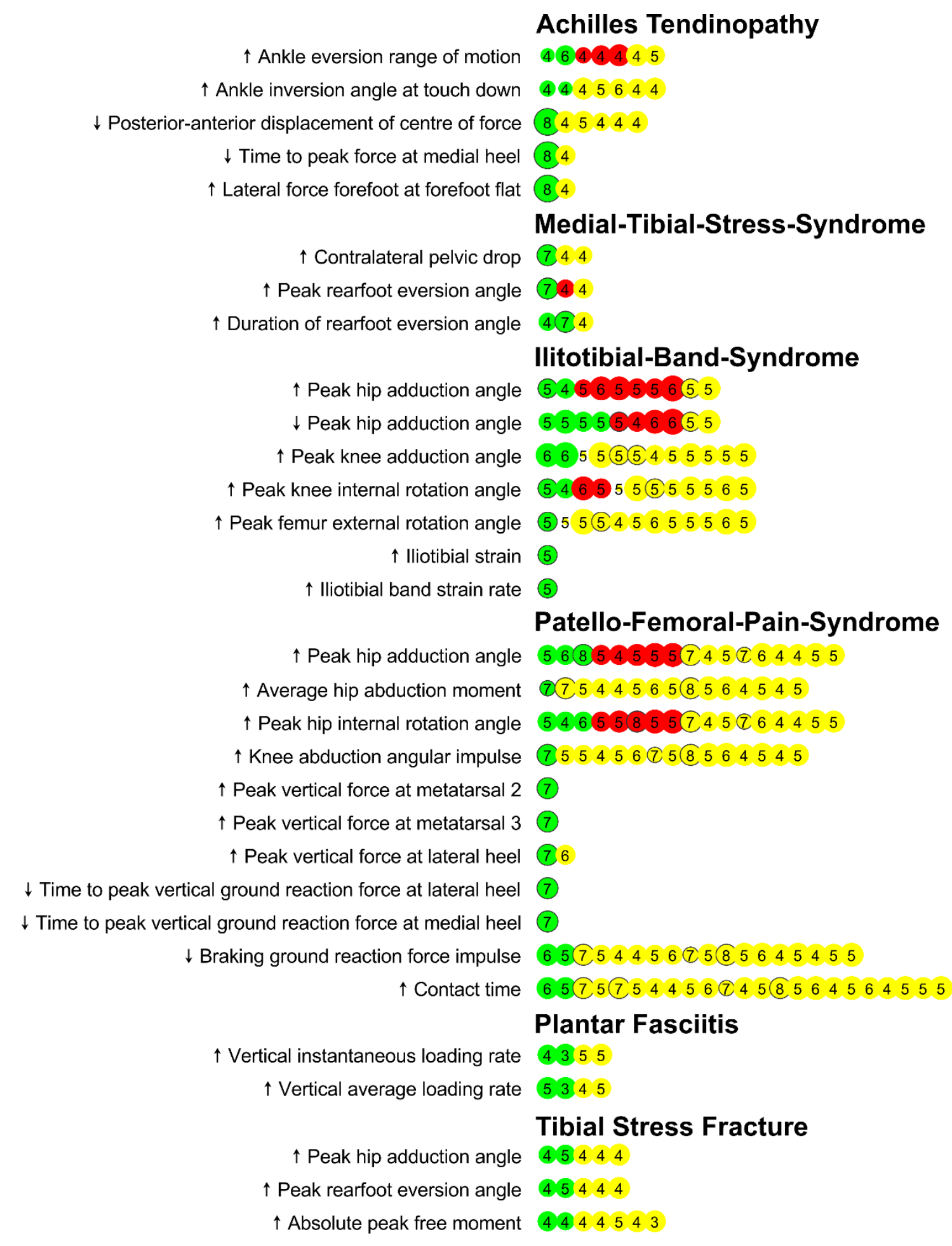

Figure 2: Graphical representation of the evidence associated with running-related risk factors that have passed our predefined relevance criterion (at least a significant difference in one prospective study or two retrospective studies). The green color represents a study that had found a significant difference between a group of injured runners compared to control. Red colors represent a study that could not find a significant difference between groups. Yellow colors represent studies that could have analysed a certain running-related risk factor based on the methodology they have used, but they did not consider the risk factor in their analysis. Black circles around dots indicate a prospective study design (no circles = retrospective study design). Dot size scales with Black \& Down quality rating of the studies. The number in the dots is the Risk of Bias Score of the study. 
medRxiv preprint doi: https://doi.org/10.1101/2021.07.23.21261034; this version posted July 26,2021 . The copyright holder for this preprint (which was not certified by peer review) is the author/funder, who has granted medRxiv a license to display the preprint in perpetuity.

All rights reserved. No reuse allowed without permission.

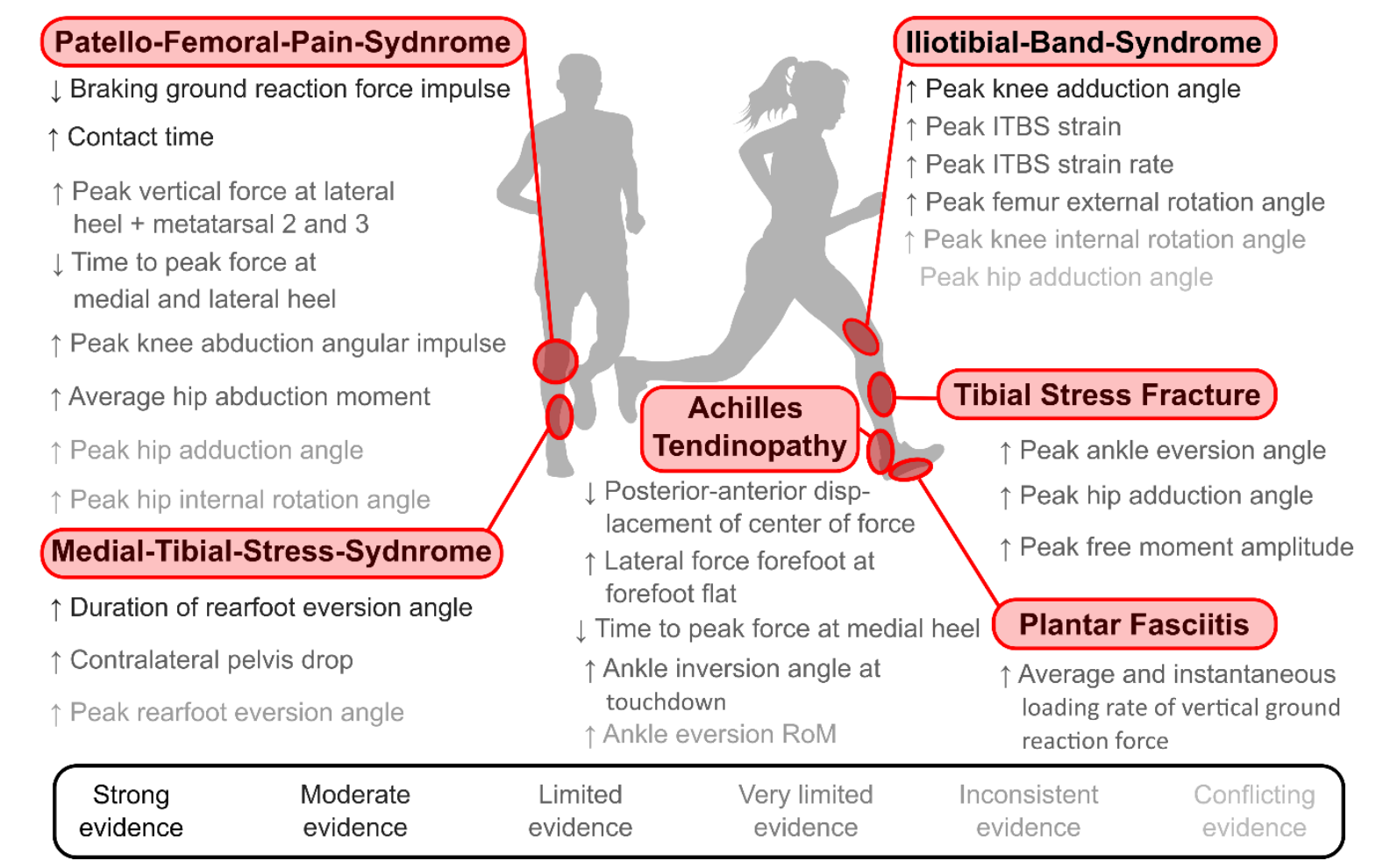

Figure 3: Overview of the evidence associated with running-related risk factors that have passed our predefined relevance criterion (at least a significant difference in one prospective study or two retrospective studies).

\section{Discussion}

This systematic review aimed to extract the evidence for RRRFs for specific ROISs from the existing literature. While there are several important previous reviews on the role of RRRFs for the development of running-related injuries, our work adds several relevant pieces to the complex puzzle of ROI development. It is the first systematic review that focuses on RRRFs for the most prevalent ROls while using the same inclusion and exclusion criteria for all considered injuries. Previous reviews either did not report overuse injuries for specific types of injuries [18] or focus on a single overuse injury [15,80-88]. Further, some reviews did only focus on prospective studies [18]. While these studies are superior in their strength of evidence to retrospective studies, the majority of research on RRRFs for ROls have used retrospective designs. By applying our relevance criterion (potential RRRFs identified from at least two retrospective studies or one prospective study), we acknowledged the superior evidence of the prospective study design while at the same time including insight gained from retrospective studies.

A list of relevant RRRFs can be used to establish an individual risk profile of an individual's running biomechanics. Based on this risk profile, individualised footwear could be developed, or footwear might be reconsidered to change the running biomechanics towards a less risky profile. Considering specific injuries is significant progress for injury profiling since running shoes can be designed to shift loading between musculoskeletal structures in the lower extremity and hence specifically address injury-specific risk factors [5]. A running injury risk profile can also inform prevention training programs to strengthen biological tissues at risk or help to develop feedback tools that facilitate running gait retraining towards a less pronounced risk profile. More sophisticated, while at the same time easy-to-use (maybe integrated with running apparel), tools for gait retraining may be available in the future [89]. 
medRxiv preprint doi: https://doi.org/10.1101/2021.07.23.21261034; this version posted July 26,2021 . The copyright holder for this preprint (which was not certified by peer review) is the author/funder, who has granted medRxiv a license to display the preprint in perpetuity.

All rights reserved. No reuse allowed without permission.

Since a previous injury is an essential non-running related injury risk factor [90], it seems logical that individualised running shoe design, prevention training protocols, or running gait feedback tools should weigh specific RRRFs based on injury history.

Further, it has to be clearly mentioned that RRRFs should be viewed in interaction with workload characteristics of training protocols and individual, structure specific load tolerance levels. This means that an individual risk profile based on RRRFs and potentially other risk factors can only inform interventions for runners if workload characteristics and stress tolerance levels are considered. Clearly more research is needed to improve our understanding on these different aspects of ROI development.

\section{Limitations}

One of the strengths of our review is that it systematically assessed the current evidence for biomechanical RRRFs specifically for the most prevalent ROls using the same methodology. Further, it includes work from both, propsepective and retrospective studies while acknowledging the superior level of evidence of prospective studies by applying a relevance criterion for retrospective study inclusion. Finally it highlights the potential for a more effective data usage by identying how additional RRRFs could have been analysed already in previous studies in the past.

Despite the several strengths of this work, we need to also highlight several limitations: Due to the lack of results reported or analysed in the considered studies, we could not differentiate our findings for different groups of runners. Since different groups of runners likely vary in their structure specific stress tolerance levels and their adaptations we recommend that future work on RRRFs should always report as many details of the running population as possible.

Further, different studies used heterogeneous definitions of injury, the definition of types of runners (e.g., competitive vs. recreational), and outcome measures in the included full-text articles challenged comparison across studies. Also, most studies did not consider running volume in their assessment of injury risk between groups (e.g., Incidence per 1000h of running [2]) or tried to quantify workload characteristics by other means.

\section{Outlook}

Based on the findings of this review and when considering recent injury development frameworks, we propose the following directions for future research. These directions can be broadly categorised by either using larger datasets with lower data precision or smaller datasets with higher precision.

The big data macroscopic approach can leverage the recent developments in wearable sensor technology and artificial intelligence. At this time, running movement data can be captured during every training session and uploaded to large databases. The insight gained from the big data approach relies on the ability to determine relevant features (i.e., functional or discrete features related to injury risk) from these sensor signals, with the assistance of artificial intelligence. The parameters identified from this review can serve as a starting point for such a data exploration. Future studies need to explore the potential to identify new RRRFs using wearable, inexpensive sensor technology outside the laboratory setting. Further, tools to collect and store data on large scales while using user feedback to label the occurrence of running-related pain or injuries will allow further insight by considering not only single data collection sessions but, in principle, the entire training history of an individual (e.g., changes associated with fatigue) [91-93]. International research collaborations that use the same methodology for data capturing and labeling seem ideally suited to solve this task.

The current review findings also highlight that there already exists a "data treasure" from research performed over the last few decades which could be reanalysed by considering 
medRxiv preprint doi: https://doi.org/10.1101/2021.07.23.21261034; this version posted July 26,2021 . The copyright holder for this preprint (which was not certified by peer review) is the author/funder, who has granted medRxiv a license to display the preprint in perpetuity.

All rights reserved. No reuse allowed without permission.

recent findings. Figure 2 highlights that several RRRFs could be analysed from existing datasets. A statistical reanalysis of the differences between injured and non-injured groups for these RRRFs from previous studies would help paint a clearer picture of the relationship between RRRFs and specific running injuries.

The small data microscopic approach relies on improvements in biomechanical modeling approaches that can improve our understanding of how running biomechanics are linked to the stress of the tissues involved in ROls. Here, the combination of individualised musculoskeletal models with, for example, finite element models of the tissues under consideration seems to offer enormous potential for not only improved targeting of runner populations at risk but also increased understanding of cause effect relationships in ROI development. Single subjects study designs applying very detailed modelling techniques might further improve our understanding of injury development since the etiology of an injury is not the same for all patients diagnosed with the same injury. However, currently, these techniques are time-consuming and rely on many assumptions that challenge the validity of the calculated stress characteristics. Therefore, the discipline of biomechanics should also target a more efficient yet precise quantification of input variables for these model calculations.

Independent of the scale and precision, running-related risk factors should not be considered in isolation but need to be analysed while considering the complex framework of running injury aetiology [11]. Therefore, the interplay of RRRFs with other modifiable and non-modifiable risk factors, workload characteristics [7], and estimators of structure-specific stress tolerance levels should be included in data collections and statistical analyses. A consensus on the minimum number and type of such framework variables for running injury research seems urgently needed to face this challenge.

In summary, this is the first systematic review that summarises the evidence for RRRFs for specific ROls using the same search strategy and exclusion and inclusion criteria. We hope that this work can serve as the basis to identify runners at risk for specific ROls and and from this basis improve decisions on footwear design or use, training and rehabilitation programs, and sensor-based devices to monitor and improve individual running biomechanics.

\section{Acknowledgements}

There are no competing interests to declare. The preparation of this review was not financially supported.

\section{References}

1 van Gent RN, Siem D, van Middelkoop M, et al. Incidence and determinants of lower extremity running injuries in long distance runners: a systematic review * COMMENTARY. British Journal of Sports Medicine 2007;41:469-80. doi:10.1136/bjsm.2006.033548

2 Videbæk S, Bueno AM, Nielsen RO, et al. Incidence of Running-Related Injuries Per $1000 \mathrm{~h}$ of running in Different Types of Runners: A Systematic Review and Meta-Analysis. Sports Med 2015;45:1017-26. doi:10.1007/s40279-015-0333-8

3 Hreljac A. Etiology, Prevention, and Early Intervention of Overuse Injuries in Runners: a Biomechanical Perspective. Physical Medicine and Rehabilitation Clinics 2005;16:651-67. doi:10.1016/j.pmr.2005.02.002 
medRxiv preprint doi: https://doi.org/10.1101/2021.07.23.21261034; this version posted July 26,2021 . The copyright holder for this preprint (which was not certified by peer review) is the author/funder, who has granted medRxiv a license to display the preprint in perpetuity.

All rights reserved. No reuse allowed without permission.

4 Malisoux L, Nielsen RO, Urhausen A, et al. A step towards understanding the mechanisms of running-related injuries. Journal of Science and Medicine in Sport 2015;18:523-8. doi:10.1016/j.jsams.2014.07.014

5 Willwacher S. Running Shoes: Injury Protection and Performance Enhancement. In: Müller B, Wolf SI, Brueggemann G-P, et al., eds. Handbook of Human Motion. Springer International Publishing 2017. 1-16. doi:10.1007/978-3-319-30808-1_121-1

6 Edwards WB. Modeling Overuse Injuries in Sport as a Mechanical Fatigue Phenomenon. Exercise and Sport Sciences Reviews 2018;46:224-31. doi:10.1249/JES.0000000000000163

7 Nielsen RO, Bertelsen ML, Møller M, et al. Training load and structure-specific load: applications for sport injury causality and data analyses. Br J Sports Med 2018;52:1016-7. doi:10.1136/bjsports-2017-097838

8 Hicks JL, Uchida TK, Seth A, et al. Is My Model Good Enough? Best Practices for Verification and Validation of Musculoskeletal Models and Simulations of Movement. Journal of Biomechanical Engineering 2015;137. doi:10.1115/1.4029304

9 Schooling CM, Jones HE. Clarifying questions about "risk factors": predictors versus explanation. Emerging Themes in Epidemiology 2018;15:10. doi:10.1186/s12982-018-0080-z

10 Meeuwisse WH, Tyreman H, Hagel B, et al. A Dynamic Model of Etiology in Sport Injury: The Recursive Nature of Risk and Causation. Clinical Journal of Sport Medicine 2007;17:215-9. doi:10.1097/JSM.0b013e3180592a48

11 Bertelsen ML, Hulme A, Petersen J, et al. A framework for the etiology of running-related injuries. Scandinavian Journal of Medicine \& Science in Sports 2017;27:1170-80. doi:10.1111/sms.12883

12 Lopes AD, Hespanhol LC, Yeung SS, et al. What are the Main Running-Related Musculoskeletal Injuries? Sports Med 2012;42:891-905. doi:10.1007/BF03262301

13 Moher D, Liberati A, Tetzlaff J, et al. Preferred reporting items for systematic reviews and metaanalyses: the PRISMA statement. PLoS Med 2009;6:e1000097. doi:10.1371/journal.pmed.1000097

14 Ouzzani M, Hammady H, Fedorowicz Z, et al. Rayyan-a web and mobile app for systematic reviews. Systematic Reviews 2016;5. doi:10.1186/s13643-016-0384-4

15 Barton $\mathrm{CJ}$, Levinger $\mathrm{P}$, Menz HB, et al. Kinematic gait characteristics associated with patellofemoral pain syndrome: a systematic review. Gait Posture 2009;30:405-16. doi:10.1016/j.gaitpost.2009.07.109

16 Downs SH, Black N. The feasibility of creating a checklist for the assessment of the methodological quality both of randomised and non-randomised studies of health care interventions. Journal of Epidemiology \& Community Health 1998;52:377-84. doi:10.1136/jech.52.6.377

17 Neal BS, Barton CJ, Gallie R, et al. Runners with patellofemoral pain have altered biomechanics which targeted interventions can modify: A systematic review and meta-analysis. Gait \& Posture 2016;45:69-82. doi:10.1016/j.gaitpost.2015.11.018 
medRxiv preprint doi: https://doi.org/10.1101/2021.07.23.21261034; this version posted July 26,2021 . The copyright holder for this preprint (which was not certified by peer review) is the author/funder, who has granted medRxiv a license to display the preprint in perpetuity.

All rights reserved. No reuse allowed without permission.

18 Ceyssens L, Vanelderen R, Barton C, et al. Biomechanical Risk Factors Associated with RunningRelated Injuries: A Systematic Review. Sports Med 2019;49:1095-115. doi:10.1007/s40279-01901110-z

19 van Tulder M, Furlan A, Bombardier C, et al. Updated Method Guidelines for Systematic Reviews in the Cochrane Collaboration Back Review Group. Spine 2003;28:1290-9. doi:10.1097/01.BRS.0000065484.95996.AF

20 Becker J, James S, Wayner R, et al. Biomechanical Factors Associated With Achilles Tendinopathy and Medial Tibial Stress Syndrome in Runners. Am J Sports Med 2017;45:2614-21. doi:10.1177/0363546517708193

21 Van Ginckel A, Thijs Y, Hesar NGZ, et al. Intrinsic gait-related risk factors for Achilles tendinopathy in novice runners: A prospective study. Gait \& Posture 2009;29:387-91. doi:10.1016/j.gaitpost.2008.10.058

22 Ryan M, Grau S, Krauss I, et al. Kinematic Analysis of Runners with Achilles Mid-Portion Tendinopathy. Foot Ankle Int 2009;30:1190-5. doi:10.3113/FAl.2009.1190

23 Williams DSB, Zambardino JA, Banning VA. Transverse-Plane Mechanics at the Knee and Tibia in Runners With and Without a History of Achilles Tendonopathy. J Orthop Sports Phys Ther 2008;38:761-7. doi:10.2519/jospt.2008.2911

24 Wyndow N, Cowan SM, Wrigley TV, et al. Triceps surae activation is altered in male runners with Achilles tendinopathy. Journal of Electromyography and Kinesiology 2013;23:166-72. doi:10.1016/j.jelekin.2012.08.010

25 Creaby MW, Honeywill C, Franettovich Smith MM, et al. Hip Biomechanics Are Altered in Male Runners with Achilles Tendinopathy. Medicine \& Science in Sports \& Exercise 2017;49:549-54. doi:10.1249/MSS.0000000000001126

26 Azevedo LB, Lambert MI, Vaughan CL, et al. Biomechanical variables associated with Achilles tendinopathy in runners. British Journal of Sports Medicine 2009;43:288-92.

doi:10.1136/bjsm.2008.053421

27 Franettovich Smith MM, Honeywill C, Wyndow N, et al. Neuromotor Control of Gluteal Muscles in Runners with Achilles Tendinopathy: Medicine \& Science in Sports \& Exercise 2014;46:594-9. doi:10.1249/MSS.0000000000000133

28 McCrory JL, Martin DF, Lowery RB, et al. Etiologic factors associated with Achilles tendinitis in runners. Med Sci Sports Exerc 1999;31:1374-81.

29 Baur H, Müller S, Hirschmüller A, et al. Comparison in lower leg neuromuscular activity between runners with unilateral mid-portion Achilles tendinopathy and healthy individuals. Journal of Electromyography and Kinesiology 2011;21:499-505. doi:10.1016/j.jelekin.2010.11.010

30 Donoghue OA, Harrison AJ, Laxton P, et al. Lower Limb Kinematics of Subjects with Chronic Achilles Tendon Injury During Running. Research in Sports Medicine 2008;16:23-38. doi:10.1080/15438620701693231

31 Johnson CD, Tenforde AS, Outerleys J, et al. Impact-Related Ground Reaction Forces Are More Strongly Associated With Some Running Injuries Than Others. Am J Sports Med 2020;48:307280. doi:10.1177/0363546520950731 
medRxiv preprint doi: https://doi.org/10.1101/2021.07.23.21261034; this version posted July 26,2021 . The copyright holder for this preprint (which was not certified by peer review) is the author/funder, who has granted medRxiv a license to display the preprint in perpetuity.

All rights reserved. No reuse allowed without permission.

32 Becker J, Nakajima M, Wu WFW. Factors Contributing to Medial Tibial Stress Syndrome in Runners: A Prospective Study. Medicine and science in sports and exercise 2018;50:2092-100. doi:10.1249/MSS.0000000000001674

33 Loudon JK, Reiman MP. Lower Extremity Kinematics in Running Athletes With and Without a History of Medial Shin Pain. International journal of sports physical therapy 2012;7:356-64.

34 Schütte $\mathrm{KH}$, Seerden S, Venter R, et al. Influence of outdoor running fatigue and medial tibial stress syndrome on accelerometer-based loading and stability. Gait \& Posture 2018;59:222-8. doi:10.1016/j.gaitpost.2017.10.021

35 Meardon SA, Willson JD, Gries SR, et al. Bone stress in runners with tibial stress fracture. Clinical Biomechanics 2015;30:895-902. doi:10.1016/j.clinbiomech.2015.07.012

36 Bennell K, Crossley K, Jayarajan J, et al. Ground reaction forces and bone parameters in females with tibial stress fracture. Medicine and science in sports and exercise 2004;36:397-404. doi:10.1249/01.mss.0000117116.90297.e1

37 Crossley K, Bennell KL, Wrigley T, et al. Ground reaction forces, bone characteristics, and tibial stress fracture in male runners. Medicine \& Science in Sports \& Exercise 1999;31:1088-93.

38 Milner $\mathrm{CE}$, Ferber R, Pollard CD, et al. Biomechanical factors associated with tibial stress fracture in female runners. Medicine and science in sports and exercise 2006;38:323-8.

doi:10.1249/01.mss.0000183477.75808.92

39 Milner CE, Davis IS, Hamill J. Free moment as a predictor of tibial stress fracture in distance runners. Journal of Biomechanics 2006;39:2819-25. doi:10.1016/j.jbiomech.2005.09.022

40 Milner CE, Hamill J, Davis IS. Distinct hip and rearfoot kinematics in female runners with a history of tibial stress fracture. The Journal of orthopaedic and sports physical therapy 2010;40:59-66. doi:10.2519/jospt.2010.3024

41 Milner CE, Hamill J, Davis I. Are knee mechanics during early stance related to tibial stress fracture in runners? Clinical Biomechanics 2007;22:697-703. doi:10.1016/j.clinbiomech.2007.03.003

42 Pohl MB, Mullineaux DR, Milner CE, et al. Biomechanical predictors of retrospective tibial stress fractures in runners. Journal of biomechanics 2008;41:1160-5. doi:10.1016/j.jbiomech.2008.02.001

43 Ribeiro AP, João SMA, Dinato RC, et al. Dynamic Patterns of Forces and Loading Rate in Runners with Unilateral Plantar Fasciitis: A Cross-Sectional Study. PLoS ONE 2015;10:e0136971. doi:10.1371/journal.pone.0136971

44 Ribeiro AP, Trombini-Souza F, Tessutti VD, et al. The effects of plantar fasciitis and pain on plantar pressure distribution of recreational runners. Clinical Biomechanics 2011;26:194-9. doi:10.1016/j.clinbiomech.2010.08.004

45 Pohl MB, Hamill J, Davis IS. Biomechanical and Anatomic Factors Associated with a History of Plantar Fasciitis in Female Runners: Clinical Journal of Sport Medicine 2009;19:372-6. doi:10.1097/JSM.0b013e3181b8c270

46 Messier SP, Pittala KA. Etiologic factors associated with selected running injuries. Medicine \& Science in Sports \& Exercise 1988;20:501. 
medRxiv preprint doi: https://doi.org/10.1101/2021.07.23.21261034; this version posted July 26,2021 . The copyright holder for this preprint (which was not certified by peer review) is the author/funder, who has granted medRxiv a license to display the preprint in perpetuity.

All rights reserved. No reuse allowed without permission.

47 Brown AM, Zifchock RA, Lenhoff $M$, et al. Hip muscle response to a fatiguing run in females with iliotibial band syndrome. Human Movement Science 2019;64:181-90.

doi:10.1016/j.humov.2019.02.002

48 Brown AM, Zifchock RA, Hillstrom HJ, et al. The effects of fatigue on lower extremity kinematics, kinetics and joint coupling in symptomatic female runners with iliotibial band syndrome. Clinical Biomechanics 2016;39:84-90. doi:10.1016/j.clinbiomech.2016.09.012

49 Baker RL, Souza RB, Rauh MJ, et al. Differences in Knee and Hip Adduction and Hip Muscle Activation in Runners With and Without Iliotibial Band Syndrome. PM\&R 2018;10:1032-9. doi:https://doi.org/10.1016/j.pmrj.2018.04.004

50 Foch E, Reinbolt JA, Zhang S, et al. Associations between iliotibial band injury status and running biomechanics in women. Gait \& Posture 2015;41:706-10. doi:10.1016/j.gaitpost.2015.01.031

51 Foch $\mathrm{E}$, Milner $\mathrm{CE}$. The influence of iliotibial band syndrome history on running biomechanics examined via principal components analysis. Journal of Biomechanics 2014;47:81-6. doi:10.1016/j.jbiomech.2013.10.008

52 Noehren B, Schmitz A, Hempel R, et al. Assessment of Strength, Flexibility, and Running Mechanics in Males with Iliotibial Band Syndrome. J Orthop Sports Phys Ther 2014;44:217-22. doi:10.2519/jospt.2014.4991

53 Ferber R, Noehren B, Hamill J, et al. Competitive Female Runners With a History of Iliotibial Band Syndrome Demonstrate Atypical Hip and Knee Kinematics. J Orthop Sports Phys Ther 2010;40:52-8. doi:10.2519/jospt.2010.3028

54 Grau S, Krauss I, Maiwald C, et al. Kinematic classification of iliotibial band syndrome in runners. Scandinavian Journal of Medicine \& Science in Sports 2011;21:184-9. doi:https://doi.org/10.1111/j.1600-0838.2009.01045.x

55 Hamill J, Miller R, Noehren B, et al. A prospective study of iliotibial band strain in runners. Clinical Biomechanics 2008;23:1018-25. doi:10.1016/j.clinbiomech.2008.04.017

56 Noehren B, Davis I, Hamill J. ASB Clinical Biomechanics Award Winner 2006: Prospective study of the biomechanical factors associated with iliotibial band syndrome. Clinical Biomechanics 2007;22:951-6. doi:10.1016/j.clinbiomech.2007.07.001

57 Messier SP, Edwards DG, Martin DF, et al. Etiology of iliotibial band friction syndrome in distance runners. Medicine \& Science in Sports \& Exercise 1995;27:951-60.

58 Luz BC, dos Santos AF, de Souza MC, et al. Relationship between rearfoot, tibia and femur kinematics in runners with and without patellofemoral pain. Gait \& Posture 2018;61:416-22. doi:10.1016/j.gaitpost.2018.02.008

59 Esculier J-F, Roy J-S, Bouyer LJ. Lower limb control and strength in runners with and without patellofemoral pain syndrome. Gait \& Posture 2015;41:813-9. doi:10.1016/j.gaitpost.2015.02.020

60 Souza RB, Powers CM. Differences in Hip Kinematics, Muscle Strength, and Muscle Activation Between Subjects With and Without Patellofemoral Pain. J Orthop Sports Phys Ther 2009;39:129. doi:10.2519/jospt.2009.2885 
medRxiv preprint doi: https://doi.org/10.1101/2021.07.23.21261034; this version posted July 26,2021 . The copyright holder for this preprint (which was not certified by peer review) is the author/funder, who has granted medRxiv a license to display the preprint in perpetuity.

All rights reserved. No reuse allowed without permission.

61 Liao T-C, Keyak JH, Powers CM. Runners With Patellofemoral Pain Exhibit Greater Peak Patella Cartilage Stress Compared With Pain-Free Runners. Journal of Applied Biomechanics 2018;34:298-305. doi:10.1123/jab.2017-0229

62 Noehren B, Hamill J, Davis I. Prospective Evidence for a Hip Etiology in Patellofemoral Pain: Medicine \& Science in Sports \& Exercise 2013;45:1120-4. doi:10.1249/MSS.0b013e31828249d2

63 Eskofier B, Kraus M, Worobets J, et al. Pattern classification of kinematic and kinetic running data to distinguish gender, shod/barefoot and injury groups with feature ranking. Computer methods in biomechanics and biomedical engineering 2011;15:467-74. doi:10.1080/10255842.2010.542153

64 Willson JD, Sharpee R, Meardon SA, et al. Effects of step length on patellofemoral joint stress in female runners with and without patellofemoral pain. Clinical biomechanics 2014;29:243-7.

65 Dierks TA, Manal KT, Hamill J, et al. Proximal and Distal Influences on Hip and Knee Kinematics in Runners With Patellofemoral Pain During a Prolonged Run. J Orthop Sports Phys Ther 2008;38:448-56. doi:10.2519/jospt.2008.2490

66 Boldt AR, Willson JD, Barrios JA, et al. Effects of Medially Wedged Foot Orthoses on Knee and Hip Joint Running Mechanics in Females With and Without Patellofemoral Pain Syndrome. Journal of Applied Biomechanics 2013;29:68-77. doi:10.1123/jab.29.1.68

67 Stefanyshyn DJ, Stergiou P, Lun VMY, et al. Knee Angular Impulse as a Predictor of Patellofemoral Pain in Runners. Am J Sports Med 2006;34:1844-51. doi:10.1177/0363546506288753

68 Willson JD, Kernozek TW, Arndt RL, et al. Gluteal muscle activation during running in females with and without patellofemoral pain syndrome. Clinical Biomechanics 2011;26:735-40. doi:10.1016/j.clinbiomech.2011.02.012

69 Willson JD, Davis IS. Lower extremity mechanics of females with and without patellofemoral pain across activities with progressively greater task demands. Clinical Biomechanics 2008;23:203-11. doi:10.1016/j.clinbiomech.2007.08.025

70 Thijs Y, De Clercq D, Roosen P, et al. Gait-related intrinsic risk factors for patellofemoral pain in novice recreational runners. British Journal of Sports Medicine 2008;42:466-71. doi:10.1136/bjsm.2008.046649

71 Duffey MJ, Martin DF, Cannon DW, et al. Etiologic factors associated with anterior knee pain in distance runners. Medicine \& Science in Sports \& Exercise 2000;32:1825.

72 Noehren B, Pohl MB, Sanchez Z, et al. Proximal and distal kinematics in female runners with patellofemoral pain. Clinical biomechanics (Bristol, Avon) 2012;27:366-71. doi:10.1016/j.clinbiomech.2011.10.005

73 Rodrigues P, TenBroek T, Hamill J. Runners With Anterior Knee Pain Use a Greater Percentage of Their Available Pronation Range of Motion. Journal of Applied Biomechanics 2013;29:141-6. doi:10.1123/jab.29.2.141

74 Messier SP, Davis SE, Curl WW, et al. Etiologic factors associated with patellofemoral pain in runners. Medicine \& Science in Sports \& Exercise 1991;23:1008-15. 
medRxiv preprint doi: https://doi.org/10.1101/2021.07.23.21261034; this version posted July 26,2021 . The copyright holder for this preprint (which was not certified by peer review) is the author/funder, who has granted medRxiv a license to display the preprint in perpetuity.

All rights reserved. No reuse allowed without permission.

75 Besier TF, Fredericson M, Gold GE, et al. Knee Muscle Forces during Walking and Running in Patellofemoral Pain Patients and Pain-Free Controls. J Biomech 2009;42:898-905.

doi:10.1016/j.jbiomech.2009.01.032

76 Bazett-Jones DM, Cobb SC, Huddleston WE, et al. Effect of Patellofemoral Pain on Strength and Mechanics after an Exhaustive Run. Medicine \& Science in Sports \& Exercise 2013;45:1331-9. doi:10.1249/MSS.0b013e3182880019

77 Cunningham TJ, Mullineaux DR, Noehren B, et al. Coupling angle variability in healthy and patellofemoral pain runners. Clinical Biomechanics 2014;29:317-22. doi:10.1016/j.clinbiomech.2013.12.008

78 Rees D, Younis A, MacRae S. Is there a correlation in frontal plane knee kinematics between running and performing a single leg squat in runners with patellofemoral pain syndrome and asymptomatic runners? Clinical Biomechanics 2019;61:227-32. doi:10.1016/j.clinbiomech.2018.12.008

79 Grau S, Maiwald C, Krauss I, et al. What are causes and treatment strategies for patellartendinopathy in female runners? Journal of Biomechanics 2008;41:2042-6. doi:10.1016/j.jbiomech.2008.03.005

80 Aderem J, Louw QA. Biomechanical risk factors associated with iliotibial band syndrome in runners: a systematic review. BMC Musculoskelet Disord 2015;16:356. doi:10.1186/s12891-0150808-7

81 Beeson P. Plantar fasciopathy: Revisiting the risk factors. Foot and Ankle Surgery 2014;20:160-5. doi:10.1016/j.fas.2014.03.003

82 Ellis R, Hing W, Reid D. Iliotibial band friction syndrome-A systematic review. Manual Therapy 2007;12:200-8. doi:10.1016/j.math.2006.08.004

83 Louw M, Deary C. The biomechanical variables involved in the aetiology of iliotibial band syndrome in distance runners - A systematic review of the literature. Physical Therapy in Sport 2014;15:64-75. doi:10.1016/j.ptsp.2013.07.002

84 Moen MH, Tol JL, Weir A, et al. Medial tibial stress syndrome: a critical review. Sports Med 2009;39:523-46. doi:10.2165/00007256-200939070-00002

85 Mousavi SH, Hijmans JM, Rajabi R, et al. Kinematic risk factors for lower limb tendinopathy in distance runners: A systematic review and meta-analysis. Gait \& Posture 2019;69:13-24. doi:10.1016/j.gaitpost.2019.01.011

86 Sancho I, Malliaras P, Barton C, et al. Biomechanical alterations in individuals with Achilles tendinopathy during running and hopping: A systematic review with meta-analysis. Gait \& Posture 2019;73:189-201. doi:10.1016/j.gaitpost.2019.07.121

87 van der Worp H, van Ark M, Roerink S, et al. Risk factors for patellar tendinopathy: a systematic review of the literature. British Journal of Sports Medicine 2011;45:446-52.

doi:10.1136/bjsm.2011.084079

88 Winkelmann ZK, Anderson D, Games KE, et al. Risk Factors for Medial Tibial Stress Syndrome in Active Individuals: An Evidence-Based Review. Journal of Athletic Training 2016;51:1049-52. doi:10.4085/1062-6050-51.12.13 
medRxiv preprint doi: https://doi.org/10.1101/2021.07.23.21261034; this version posted July 26,2021 . The copyright holder for this preprint (which was not certified by peer review) is the author/funder, who has granted medRxiv a license to display the preprint in perpetuity. All rights reserved. No reuse allowed without permission.

89 Porciuncula F, Roto AV, Kumar D, et al. Wearable Movement Sensors for Rehabilitation: A Focused Review of Technological and Clinical Advances. PM\&R 2018;10:S220-32. doi:10.1016/j.pmrj.2018.06.013

90 van der Worp MP, ten Haaf DSM, van Cingel R, et al. Injuries in Runners; A Systematic Review on Risk Factors and Sex Differences. PLoS ONE 2015;10:e0114937. doi:10.1371/journal.pone.0114937

91 Sanno M, Willwacher S, Epro G, et al. Positive Work Contribution Shifts from Distal to Proximal Joints during a Prolonged Run. Med Sci Sports Exerc 2018;50:2507-17. doi:10.1249/MSS.0000000000001707

92 Sanno M, Epro G, Brüggemann G-P, et al. Running into Fatigue: The Effects of Footwear on Kinematics, Kinetics, and Energetics. Medicine \& Science in Sports \& Exercise 2021;Publish Ahead of Print. doi:10.1249/MSS.0000000000002576

93 Willwacher S, Sanno M, Brüggemann G-P. Fatigue matters: An intense $10 \mathrm{~km}$ run alters frontal and transverse plane joint kinematics in competitive and recreational adult runners. Gait \& Posture 2020;76:277-83. doi:10.1016/j.gaitpost.2019.11.016 